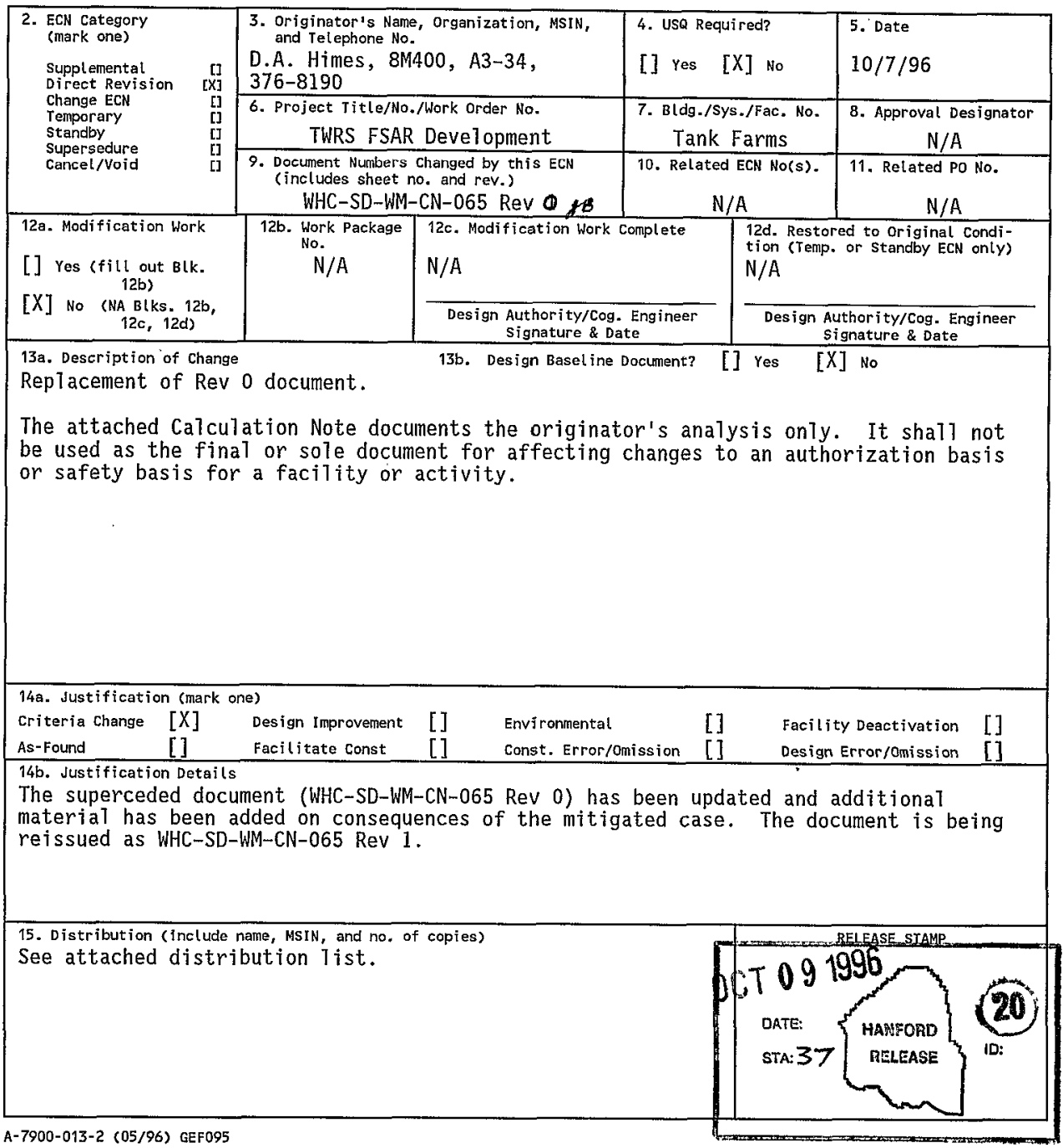




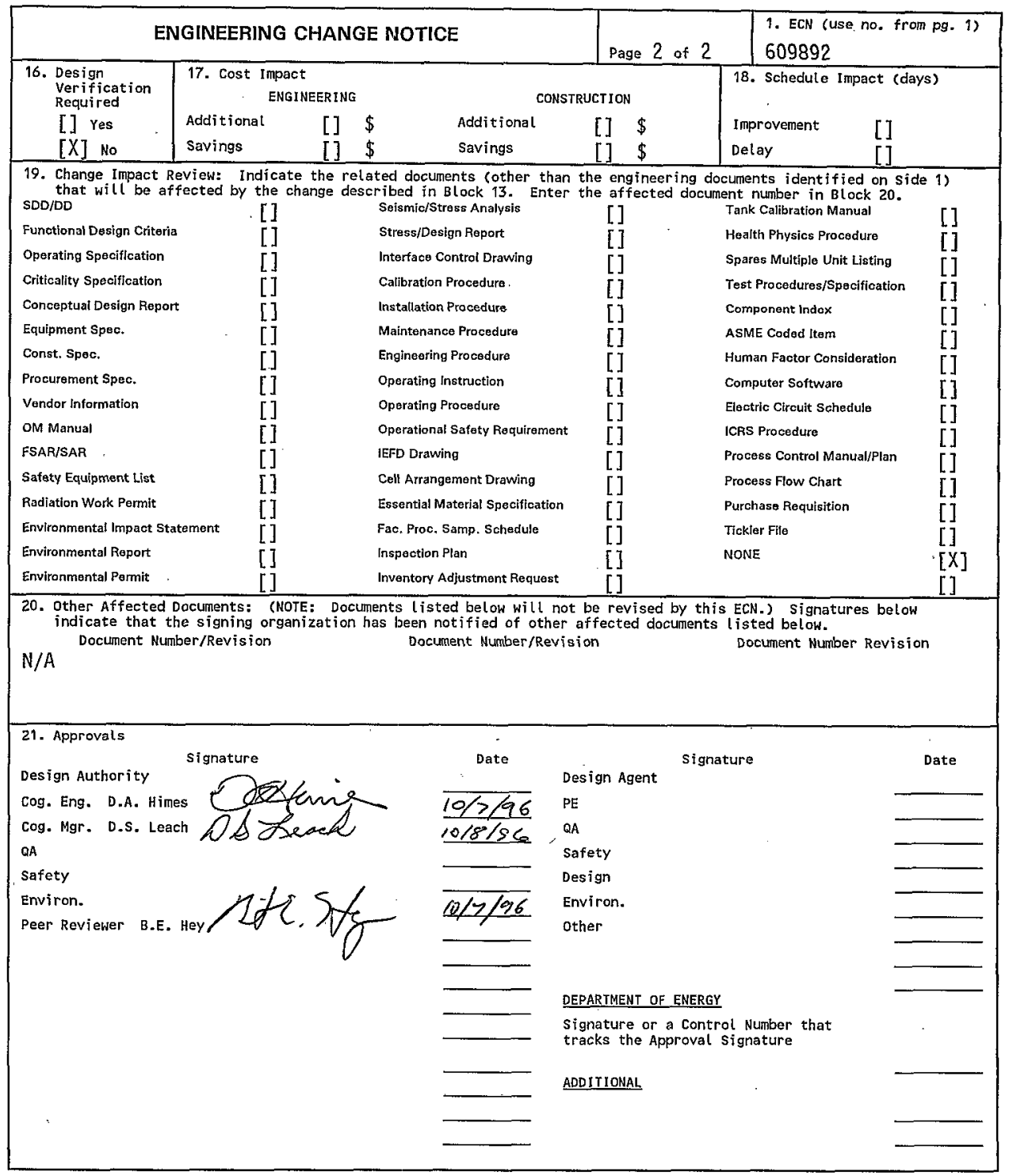




\section{Consequence Analysis of a $\mathrm{NaOH}$ Solution Spray Release During Addition to Waste Tank}

D.A. Himes

Westinghouse Hanford Company, Richland, WA 99352

U.S. Department of Energy Contract DE-AC06-87RL10930

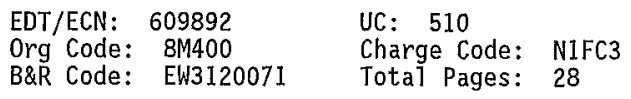

Key Words: Caustic, $\mathrm{NaOH}, \mathrm{pH}$ adjustment

Abstract: Toxicological consequences were calculated for a postulated maximum caustic soda $(\mathrm{NaOH})$ solution spray leak during addition to a waste tank to adjust tank pH. Although onsite risk guidelines were exceeded for the unmitigated release, site boundary consequences were below the level of concern. Means of mitjgating the release so as to greatly reduce the onsite consequences were recommended. Consequences for the mitigated release were estimated and both onsite and offsite consequences were found to negligible.

TRADEMARK DISCLAIMER. Reference herein to any specific commercial product, process, or service by trade name, trademark, manufacturer, or otherwise, does not necessarily constitute or imply its endorsement, recommendation, or favoring by the United States Government or any agency thereof or its contractors or subcontractors.

Printed in the United States of America. To obtain copies of this document, contact: WHC/BCS Document Control Services, P.0. Box 1970, Mailstop H6-08, Richland WA 99352, Phone (509) 372-2420; Fax (509) 376-4989.
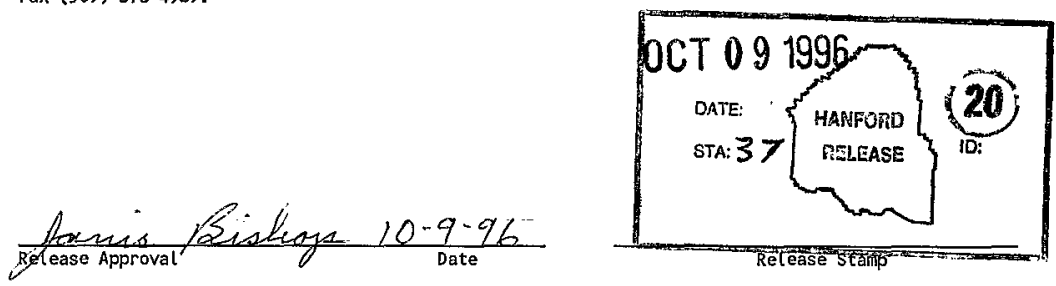


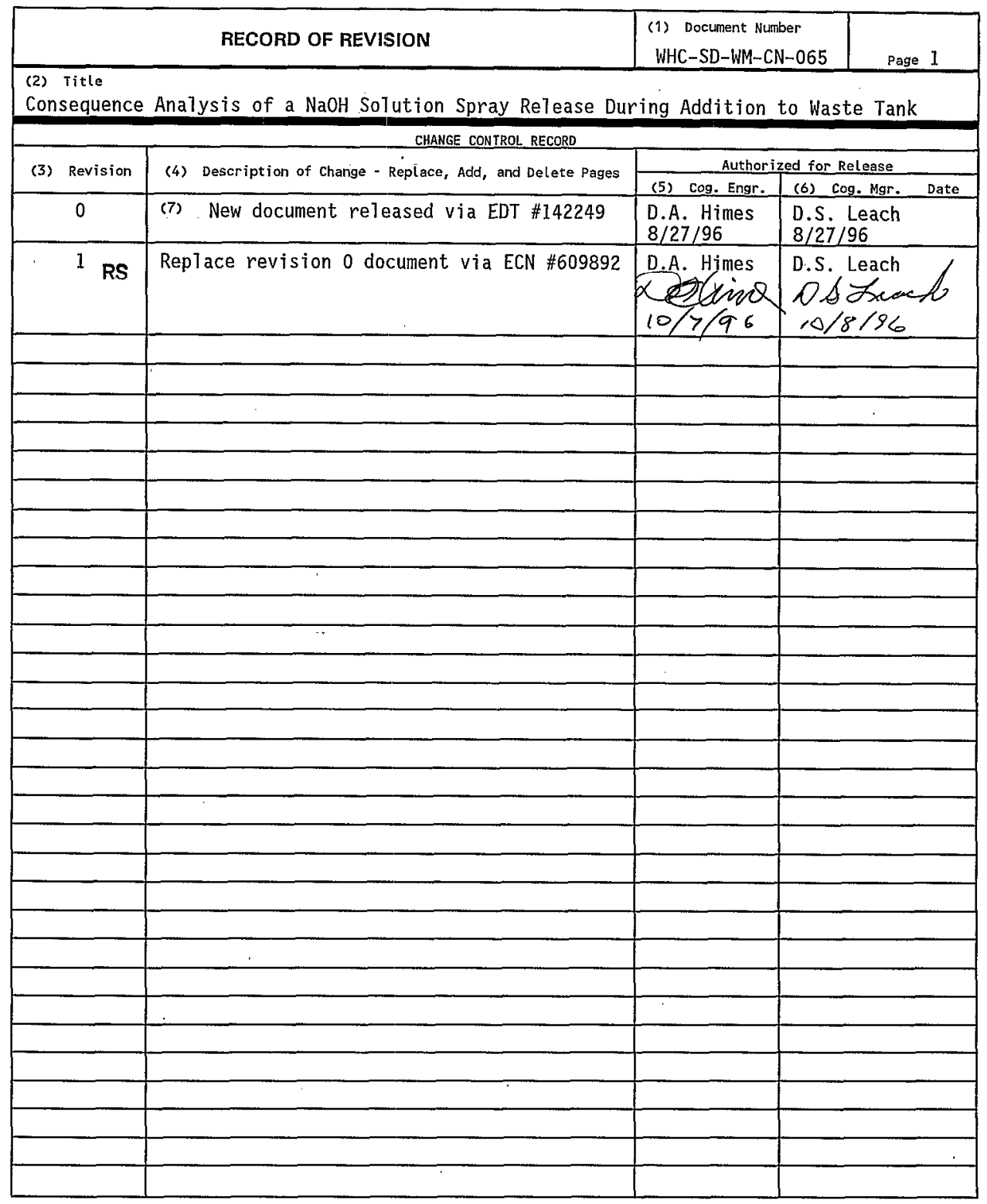




\title{
CONSEQUENCE ANALYSIS OF A NaOH SOLUTION SPRAY RELEASE DURING ADDITION TO WASTE TANK
}

\author{
D.A. Himes
}

$10 / 3 / 96$

Aqueous $\mathrm{NaOH}$ solutions are added as needed to Hanford waste tanks to adjust waste $\mathrm{pH}$ so as to minimize corrosion in the tanks. Sodium hydroxide is either (1) procured from an offsite vendor and transported in 15,140-L (4,000-gal) tanker trucks to the tank farms or (2) mixed on site. The caustic solution may be as strong as $19 \mathrm{M}(50 \mathrm{wt} \%)$. The solution may be transferred into a given tank by a mixer pump or directly through an available riser. The jightest equipment considered to be suitable for $\mathrm{NaOH}$ solution transport is 1 inch schedule 10 commercial steel pipe with a watl thickness of 0.109 inches. The largest pipe or hose considered is 2 inch cross linked polyethylene hose with a wall thickness of 25/64 inch. The maximum pressure the system can be subjected to is $125 \mathrm{psig.} \mathrm{The} \mathrm{highest} \mathrm{temperature} \mathrm{at} \mathrm{which} \mathrm{the} \mathrm{tank} \mathrm{truck} \mathrm{is}$ loaded is $120^{\circ} \mathrm{F}\left(49^{\circ} \mathrm{C}\right)$.

A pressurized spray leak of caustic solution during a transfer to a waste tank could disperse a significant amount of respirable sodium hydroxide particles. These particles could cause potentially significant onsite consequences. This analysis will (1) estimate the maximum $\mathrm{NaOH}$ air concentrations at the onsite and site boundary receptor locations and (2) develop and analyze precautions which could be taken to mitigate the onsite consequences should a spray leak develop. No radioactive materials are associated with this event.

\section{Accident description:}

A pressure of $125 \mathrm{psig}(862 \mathrm{kPa}$ ) is not expected to be able to cause schedule 10 steel pipe to fail. (Schedule 10 steel pipe is rated for a working pressure of about $850 \mathrm{psig}$ for temperatures less than $650^{\circ} \mathrm{F}$ [Chemetron 1969].) The most likely cause of a spray release is considered to be a loose connection, or possibly a cracked circumferential weld joining the pipe to a flange or fitting due to repetitive mechanical stress on the pipe. In the case of a loose fitting, the leak could extend around the futl circumference of the sealing surface. The depth (path length) of the opening in such a case, however, would be much greater than the wall thickness of the pipe and so would exhibit a much lower leak rate due to friction losses. Polyethylene is not stiff enough to maintain the fine crack width associated with an atomizing spray over a crack length sufficjent to produce a signifjcant leak rate. A split in the polyethylene hose large enough to cause a significant release rate would therefore produce a stream (with little production of small particles) rather than a fine spray. The worst case circumferential crack in a pipe weld able to maintain the narrow width associated with a fine aerosol 
spray is normally assumed to extend a distance around the pipe equal to one pipe diameter (inside).

The maximum spray leak was therefore assumed to be a crack with a minimum depth equal to the lightest (scheduTe 10) pipe waTl thickness of 0.109 inches $(2.77 \mathrm{~mm})$ and a maximum length equal to one pipe diameter, i.e., I inch (25 $\mathrm{mm})$. The width of the crack was optimized to produce the highest respirable particle fraction using the SPRAY Code (Hey and Leach 1994).

\section{Transport assumptions:}

For a ground level release the onsite receptor is normally assumed to be at a distance of $100 \mathrm{~m}$ in the worst direction (WHC 1988). The site boundary receptor for purposes of this analysis is located at the site boundary or the near bank of the Columbia River, whichever is closer, in the worst direction. No receptor evacuation was assumed.

Acute 99.5 percentile ground level release dispersion factors $(X / Q)$ have been generated for the Hanford tank farms using the GXQ code (Hey 1994) at each of the 16 sectors at $100 \mathrm{~m}$ and at the site boundary or the near bank of the Columbia River. Since maximum air concentrations are the primary concern for toxic releases, no $p]$ ume meander was assumed. The resulting $X / Q$ s are reported in WHC-SD-WM-SARR-016 Rev 2 (Van Keuren 1996) as $3.41 \mathrm{E}-2 \mathrm{~s} / \mathrm{m}^{3}$ onsite ( $100 \mathrm{~m} \mathrm{E}$ ) and $2.83 \mathrm{E}-5 \mathrm{~s} / \mathrm{m}^{3}$ at the site boundary $(8.76 \mathrm{~km} \mathrm{~N})$.

In the case of a liquid spray release, care must be taken to account for evaporation during transit when estimating the smal1 particle ("respirable") fraction. Particles less than about $10 \mu \mathrm{m}$ tend to remain suspended in the air for long distances whereas particles larger than $10 \mu \mathrm{m}$ released from a nonelevated source tend to fall out within the first 50 to $100 \mathrm{~m}$ of travel. (The term "respirable fraction" is often used in reference to particles less than $10 \mu \mathrm{m}$ because this is the size range which can reach the lower lung.) The size of the Tiquid particles will decrease in transit due to evaporation of the liquid component finally leaving only a smaller particle of the solid material which had been in solution in the liquid. The initial diameter, $D_{r}$, of a solution particle with a solid fraction $f_{s}$ which will evaporate to a particle with a diameter of $10 \mu \mathrm{m}$ is given by (Hey and Leach 1995)

$$
D_{r}=\frac{10 \mu m}{f_{s}^{\frac{1}{3}}}
$$

The resulting initial particle diameters are shown in Table 1 along with solution viscosity and density (Perry and Green 1984) for a range of solid fractions of $\mathrm{NaOH}$ in water. The leak rate and atomization efficiency increase with decreasing viscosity and hence increasing temperature. The high end of the temperature range for this liquid $\left(50^{\circ} \mathrm{C}\right)$ is therefore assumed. 
WHC-SD-WM-CN-065 ReV 1

Table 1: Concentration dependent parameters for caustic soda ( $\mathrm{NaOH})$ solutions at $50^{\circ} \mathrm{C}$

\begin{tabular}{rccc}
$\% \mathrm{NaOH}$ & $\begin{array}{c}\text { Density } \\
\left(\mathrm{g} / \mathrm{cm}^{3}\right)\end{array}$ & $\begin{array}{c}\text { Viscosity } \\
\text { (centipoise) }\end{array}$ & $\mathrm{D}_{\mathrm{r}}(\mu \mathrm{m})$ \\
\hline \hline 5 & 1.041 & 0.80 & 27.1 \\
10 & 1.094 & 0.96 & 21.5 \\
12 & 1.116 & 1.1 & 20.3 \\
15 & 1.148 & 1.3 & 18.8 \\
20 & 1.202 & 1.9 & 17.1 \\
30 & 1.309 & 4.4 & 14.9 \\
40 & 1.410 & 8.5 & 13.6 \\
50 & 1.504 & 14.3 & 12.6
\end{tabular}

It is conservatively assumed here that the liquid fraction of the spray evaporates very quickly. In reality the initial large size of the "respirable" particles would cause rapid initial fallout.

\section{Source term:}

The SPRAY Code version 3.0 (Hey and Leach 1995) was used to calculate Teak rates and small particle fractions for the assumed break (a crack with a minimum depth equal to 0.109 inches [2.77 mm] and a maximum 7 ength equal to 1 inch [25 mm]) in the liquid containment boundary. The crack width was optimized to maximize the release rate of particles with an initial size less than or equal to the size given as $D_{r}$ in Table 1 .

At low solution concentrations, the viscosity is low (approaching that of water) so that friction losses in the crack are low and solution release rates are relatively high. The $\mathrm{NaOH}$ release rate is low, however, due to the low concentration. As concentration increases, the $\mathrm{NaOH}$ respirable release rate initially stays fairly constant due to the competing effects of increasing concentration and decreasing initial particle size range due to effects of evaporation. However as concentration is increased further, the increase in solution viscosity causes a rapidly decreasing flow rate. There is also an added effect due to a transition from turbulant flow at low viscosity to Iaminar flow at higher viscosities. It is expected, therefore, that the maximum small particle $\mathrm{NaOH}$ release rate will occur at some optimum solution concentration. A parametric study was performed using the SPRAY Code to determine this optimum solution concentration within the expected range of $5 \%$ to $50 \% \mathrm{NaOH}$ to be used for tank additions. The small particle release rate was therefore calculated over a range of $\mathrm{NaOH}$ concentrations with the results shown in Table 2. Standard roughness and flow parameters for steel pipe were assumed as documented in the SPRAY Code output files shown in Attachment 1. 
For the cases where critical flow developed in the crack, friction factors for Iaminar flow were assumed for conservatism.

Table 2: Solution spray release parameters

\begin{tabular}{lllll}
$\% \mathrm{NaOH}$ & $\begin{array}{c}\text { Optimum Crack } \\
\text { Width }(\mathrm{m})\end{array}$ & $\begin{array}{c}\text { Flow } \\
\text { Type }\end{array}$ & $\begin{array}{c}\text { Respirable } \\
\text { Fraction }\end{array}$ & $\begin{array}{c}\text { Respirable } \\
\text { NaOH Release } \\
\text { Rate }(\mathrm{g} / \mathrm{s})\end{array}$ \\
\hline 5 & $9.99 \mathrm{E}-5$ & Turbulent & $7.10 \mathrm{E}-2$ & 0.193 \\
10 & $9.81 \mathrm{E}-5$ & Turbulent & $3.76 \mathrm{E}-2$ & 0.204 \\
12 & $4.60 \mathrm{E}-5$ & Critica1 & $4.12 \mathrm{E}-1$ & 1.68 \\
15 & $4.68 \mathrm{E}-5$ & Critical & $3.00 \mathrm{E}-1$ & 1.53 \\
20 & $5.34 \mathrm{E}-5$ & Laminar & $1.38 \mathrm{E}-1$ & 1.07 \\
30 & $7.77 \mathrm{E}-5$ & Laminar & $2.19 \mathrm{E}-2$ & 0.384 \\
40 & $1.05 \mathrm{E}-4$ & Laminar & $5.10 \mathrm{E}-3$ & 0.166 \\
50 & $1.35 \mathrm{E}-4$ & Laminar & $1.55 \mathrm{E}-3$ & 0.0840
\end{tabular}

As indicated in the table, the maximum small particle $\mathrm{NaOH}$ release rate corresponded to a solution concentration of $12 \%$.

\section{Results:}

By the definition of the $X / Q$, the maximum air concentration of $\mathrm{NaOH}$ at a receptor location is just the product of the maximum release rate and the receptor $X / Q$. The resulting onsite and site boundary air concentrations of small particle $\mathrm{NaOH}$ is shown in Table 3 .

Table 3: Resulting $\mathrm{NaOH}$ air concentrations

$\% \mathrm{NaOH} \quad \begin{gathered}\text { RespirabTe Release } \\ \text { Rate }(\mathrm{mg} / \mathrm{s})\end{gathered}$ Onsite $(100 \mathrm{~m}) \quad$ Site Boundary

\begin{tabular}{rlll}
\hline \hline 5 & $1.93 \mathrm{E}+2$ & $6.58 \mathrm{E}+0$ & $5.46 \mathrm{E}-3$ \\
10 & $2.04 \mathrm{E}+2$ & $6.96 \mathrm{E}+0$ & $5.77 \mathrm{E}-3$ \\
12 & $1.68 \mathrm{E}+3$ & $5.73 \mathrm{E}+1$ & $4.75 \mathrm{E}-2$ \\
15 & $1.53 \mathrm{E}+3$ & $5.22 \mathrm{E}+1$ & $4.33 \mathrm{E}-2$ \\
20 & $1.07 \mathrm{E}+3$ & $3.65 \mathrm{E}+1$ & $3.03 \mathrm{E}-2$ \\
30 & $3.84 \mathrm{E}+2$ & $1.31 \mathrm{E}+1$ & $1.09 \mathrm{E}-2$ \\
40 & $1.66 \mathrm{E}+2$ & $5.66 \mathrm{E}+0$ & $4.70 \mathrm{E}-3$ \\
50 & $8.40 \mathrm{E}+1$ & $2.86 \mathrm{E}+0$ & $2.38 \mathrm{E}-3$
\end{tabular}


These results are considered very conservative in this case since they do not take credit for the initially rapid fallout rate of the large liquid particles prior to evaporation of the Tiquid fraction.

\section{Conclusion:}

The caustic spray leak analyzed here has been assigned a frequency of occurrence in the anticipated range $\left(10^{-2}-10^{+0} / y\right)$. The risk guidel ines for onsite and site boundary receptors for this frequency range are ERPG-1 and $\mathrm{PEL}-\mathrm{TWA}$. Both criteria are $2 \mathrm{mg} / \mathrm{m}^{3}$ for $\mathrm{NaOH}$ (Van Keuren 1995). The concentrations at the receptor points and the resulting sum of fractions of the risk guidelines are shown in Table 4.

Table 4: Receptor exposures to $\mathrm{NaOH}$

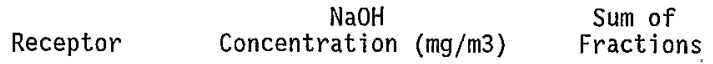

$\begin{array}{lcc}\text { Site Boundary } & & \\ \text { at } 8.76 \mathrm{~km} \mathrm{~N} & 4.75 \mathrm{E}-2 & 0.024 \\ \text { Onsite } & & \\ \text { at } 100 \mathrm{~m} \mathrm{E} & 5.73 \mathrm{E}+1 & 29\end{array}$

The sum of fractions at the site boundary are far less than the toxicological risk criterion of 1 . The criterion is exceeded at the onsite receptor location.

Note that these results are for standard schedule 10 steel pipe. Use of a thinner wall pipe such as schedule 5 (wall thickness 0.065 in.) would increase the maximum release rate and receptor concentrations shown in Tables 3 and 4 by about $30 \%$ (due to the smaller crack depth and decreased friction losses). There would be no changes in the conclusions.

\section{Recommendations for mitiqation:}

Since the liquid being transferred is relatively $\operatorname{cool}\left(<50^{\circ} \mathrm{C}\right)$ and is at relatively low pressure ( $\leq 125 \mathrm{psig}$ ), containment of a possible spray release would be easy. Plastic sleeving or wrap taped in place around the fittings would be sufficient to contain the spray. Using the total optimal leak rate of $3.04 \mathrm{E}-5 \mathrm{~m}^{3} / \mathrm{s}$ (see attached Spray Code run for $12 \%$ solution) and the crack area produces a maximum liquid spray velocity of $26 \mathrm{~m} / \mathrm{s}$. Even assuming the spray to come out in a parallel (rather than a radial) stream, the maximum resulting reaction force of the worst-case spray would be about $0.88 \mathrm{Nt}(0.20$ 1b). Assuming the plastic to form a $90^{\circ}$ corner under the impact of the spray, the maximum stress produced in $4 \mathrm{mi} T$ material would be about $35 \mathrm{psi}$. Standard 4 mil polyethylene (or similar material) sleeving or wrap would therefore have 
ample strength to contain the spray. The sleeving/wrap would not be expected to be pressure tight, however, and the solution would stitl Teak out, producing a minor local cleanup problem, but there would be no significant aerosol release.

The aerosol release rate for the mitigated spray can be estimated by calculating how much mist generated inside the plastic sleaving could be displaced out of the sleaving by the solution leaking out of the pipe. The maximum total solution Teak rate equal to $7.18 \mathrm{E}-5 \mathrm{~m} / \mathrm{s}$ occurs at a solution concentration of $50 \%$ (see the GXQ results for $50 \%$ solution in attachment 1 ). This total leak rate is assumed to displace the same amount of air out of the sleaving. The maximum air loading of an aerosol mist is normally assumed to be $100 \mathrm{mg} / \mathrm{m}^{3}$ (ANSI N46.1 1980). However, since the air loading here is for a short-time transient condition, ten times this value, or $1 \mathrm{~g} / \mathrm{m}^{3}$ is assumed for conservatism. Then assuming that no liquid is leaking from the sleaving (it is just filling with 7 iquid), a displaced volume rate of $7.18 \mathrm{E}-5 \mathrm{~m} / \mathrm{s}$ would force $7.18 \mathrm{E}-5 \mathrm{~g} / \mathrm{s}$ of solution, or $3.59 \mathrm{E}-2 \mathrm{mg} / \mathrm{s}$ of $\mathrm{NaOH}$, out of the sleaving. Using the same transport assumptions as before, the resulting receptor concentrations are $1.22 \mathrm{E}-3 \mathrm{mg} / \mathrm{m}^{3}$ and $1.02 \mathrm{E}-6 \mathrm{mg} / \mathrm{m}^{3}$ for the onsite and site boundary receptors, respectively. Both concentrations are negligible compared to the risk guidelines of $2 \mathrm{mg} / \mathrm{m}^{3}$ for both receptors. 


\section{References:}

ANSI N46.1, 1980, American Nationa7 Standard - Guidance for Defining SafetyRelated Features of Nuclear Fuel Cycle Facilities, American Nuclear Society, La Grange Park, Illinois.

Chemetron 1969, Piping Engineering, Tube Turns Division of Chemetron Corporation, Louisville, Kentucky, October 1969.

Hey 1994, B.E. Hey, GXQ Program User's Guide, WHC-SD-GN-SWD-30002, Rev. 1, December 1994.

Hey and Leach 1994, B.E. Hey and D.S. Leach, A Model for Predicting Respirable Releases from Pressurized Leaks, WHC-SD-GN-SWD-20007 Rev 0, Aprit 1994.

Perry and Green 1984, R.H. Perry and D. Green, Perry's Chemical Engineers' Handbook, Sixth Edition, McGraw-Hill, New York, 1984.

Van Keuren 1996, J.C. Van Keuren, Tank Waste Compositions and Atmospheric Dispersion Coefficients for use in Accelerated Safety Analysis Consequence Assessments, WHC-SD-WM-SARR-016 Rev 2, JuTy 1996.

Van Keuren 1995, J.C. Keuren, J.S. Davis, and M.L. Dentler, Toxic Chemical Considerations for Tank Farm Releases, WHC-SD-WM-SARR-01 I Rev I, November 1995.

WHC 1996, Safety Assessment for Tank 241-C-106 Waste Retrieval Project $W-320$, WHC-SD-WM-SAD-024 Rev 0, May 1996. 
WHC-SD-WM-CN-065 Rev 1

Attachment 1

SPRAY Code Fites

8 of 26 
WHC-SD-WM-CN-065 Rev 1

SPRAY Version 3.0

May 3, 1994

Spray Leak Code

Produced by Radiological \& Toxicological Analysis

Westinghouse Hanford Company

Run Date $=08 / 21 / 96 /$

Run Time $=08: 03: 04.56$

INPUT ECHO:

c unmitigated caustic spray - $5 \% \mathrm{NaOH}$

c SPRAY Version 3 Input Deck

c mode iflow jopt

$200 \quad T$

$c$

c MODEL OPTIONS:

c mode $=1$ then orifice leak with friction assumed

c $\quad 2$ then sTit leak with friction assumed

c iflow $=0$ Reynold's number determines friction relation (i.e. laminar or turb.

c $\quad=1$ friction based on laminar relation

c $=2$ friction based on turbutent relation

c iopt $=T$ then optimal diameter search performed

$c \quad=F$ then no optimal search

c

c PARAMETER INPUT:

c Initial slit

c Width or Slit

c Orifice Dia. Length

c (in) (in)

c

\section{$\overline{1.00000 \mathrm{E}-03} \overline{1.00000 \mathrm{E}+00} \quad \overline{1.09000 \mathrm{E}-01}$}

c

$\mathrm{c}$

c

c

c

c Pressure

c Differential

c (psi)

Absolute

Surface

Roughness

(in)

0.00006 tube

STit or

Orifice

Depth

(in)

c

\section{$1.25000 \mathrm{E}+02$}

0.0018 steel

0.0102 iron

Contraction Coefficient

0.61 and

Ve]ocity

Coefficient

0.98 for sharp edge orifice

1.00 and

0.98 for rounded orifice

1.00 and

0.82 for square edge orifice

$\overline{1.80000 \mathrm{E}-03}$

$\widetilde{1.00000 \mathrm{E}+00}$

$8.20000 \mathrm{E}-01$ 


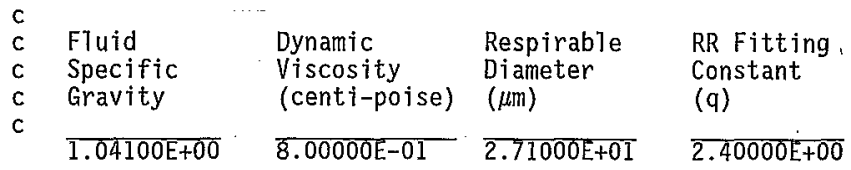

MESSAGES:

ST it Mode?

Code search for optimal equivalent diameter.

\section{OUTPUT:}

Liquid Velocity $=6.76 \mathrm{E}+01 \mathrm{ft} / \mathrm{s} \quad 2.06 \mathrm{E}+01 \mathrm{~m} / \mathrm{s}$

Reynolds Number $=5.33 \mathrm{E}+03$ Turbulent Flow

Sauter Mean Diameter $=5.26 \mathrm{E}+01 \mu \mathrm{m}$

Optimum Slit Width $=3.93 \mathrm{E}-03$ in

Respirab]e Fraction $=7.10 \mathrm{E}-02$

Total Leak Rate $=8.28 \mathrm{E}-01 \mathrm{gpm}$

Respirab7e Leak Rate $=5.88 \mathrm{E}-02 \mathrm{gpm}$

9.99E-05 m

$5.22 \mathrm{E}-05 \mathrm{~m} 3 / \mathrm{s}$

$3.71 \mathrm{E}-06 \mathrm{~m} 3 / \mathrm{s}$

$5.44 \mathrm{E}+01 \mathrm{~g} / \mathrm{s}$

$3.86 \mathrm{E}+00 \mathrm{~g} / \mathrm{s}$ 
WHC-SD-WM-CN-065 Rev 1

SPRAY Version 3.0

May 3, 1994

Spray Leak Code

Produced by Radiological \& Toxicological Analysis

Westinghouse Hanford Company

Run Date $=08 / 21 / 96 /$

Run Time $=08: 08: 31.64$

INPUT ECHO:

c unmitigated caustic spray - $10 \% \mathrm{NaOH}$

c SPRAY Version 3 Input Deck

c mode iflow iopt

$\begin{array}{lll}2 & 0 & T\end{array}$

c

c MODEL OPTIONS:

$c$ mode $=1$ then orifice leak with friction assumed

c 2 then slit Teak with friction assumed

$c$ iflow $=0$ Reynold's number determines friction relation (i.e. laminar or turb.

$c=1$ friction based on laminar relation

$c \quad=2$ friction based on turbulent relation

c iopt $=\mathrm{T}$ then optimal diameter search performed

c $=F$ then no optimal search

c

c PARAMETER INPUT:

c

c Initial S1it

c Width or

c Orifice Dia.

c (in)

c

$\overline{1.00000 \mathrm{E}-03}$.

S1it

Length

Slit or

(in)

Orifice

Depth

(in)

C

C

c

c

c

c

c

c

$\overline{1.00000 E+00}$

$\longdiv { 1 . 0 9 0 0 0 \mathrm { E } - 0 1 }$

Absolute

Surface

Roughness

(in)

Differential

0.00006 tube

Contraction

Coefficient

Velocity

Coefficient

(psi)

0.0018 steel

0.61 and

0.98 for sharp edge orifice

1.00 and

0.98 for rounded orifice

0.0102 iron

1.00 and

0.82 for square edge orifice

$\overline{1.25000 E+02}$

$\overline{1.80000 \text { E- } 03}$

$\overline{1.00000 E+00}$

8.20000 E-01

11 of 26 
C

c Fiujd

Dynamic

Viscosity

Respirable

RR Fitting

c Specific

(centi-poise)

Diameter

Gravity

$(\mu \mathrm{m})$

Constant

c

$\overline{1.09400 E+00}$

$\overline{9.60000 E-01}$

2.15000E+01

(q)

$\overline{2.40000 E+00}$

MESSAGES:

S1 it Model

Code search for optimal equivalent diameter.

\section{OUTPUT:}

Liquid VeTocity $=6.53 E+01 \mathrm{ft} / \mathrm{s} \quad 1.99 \mathrm{E}+01 \mathrm{~m} / \mathrm{s}$

Reynolds Number $=4.43 \mathrm{E}+03$ Turbulent Flow

Sauter Mean Diameter $=5.48 \mathrm{E}+01 \mu \mathrm{m}$

Optimum S7 it Width $=3.86 \mathrm{E}-03$ in

Respirable Fraction $=3.76 \mathrm{E}-02$

Total Leak Rate $=7.86 \mathrm{E}-01 \mathrm{gpm}$

Respirable Leak Rate $=2.96 \mathrm{E}-02 \mathrm{gpm}$

9.81E-05 m

$4.96 \mathrm{E}-05 \mathrm{~m} 3 / \mathrm{s}$

$1.87 \mathrm{E}-06 \mathrm{~m} 3 / \mathrm{s}$

$5.42 \mathrm{E}+01 \mathrm{~g} / \mathrm{s}$

$2.04 \mathrm{E}+00 \mathrm{~g} / \mathrm{s}$ 
WHC-SD-WM-CN-065 Rev 1

SPRAY Version 3.0

May 3,1994

\section{Spray Leak Code}

Produced by Radiological \& Toxicological Analysis

Westinghouse Hanford Company

Run Date $=08 / 21 / 96 /$

Run Time $=08: 24: 57.06$

\section{INPUT ECHO:}

c unmitigated caustic spray - $12 \% \mathrm{NaOH}$

c SPRAY Version 3 Input Deck

c mode iflow iopt

C

$2{ }_{1} \mathrm{~T}$

c MODEL OPTIONS:

$c$ mode $=1$ then orifice leak with friction assumed

c 2 then slit leak with friction assumed

c iflow $=0$ Reynold's number determines friction relation (i.e. laminar or turb.

c $\quad=1$ friction based on laminar relation

$c \quad=2$ friction based on turbulent retation

$c$ jopt $=T$ then optimal diameter search performed

c $\quad=F$ then no optimal search

$\mathrm{C}$

c PARAMETER INPUT:

$\mathrm{C}$

c Initial S1it

c Width or STit

c Orifice Dia. Length

c (in)

c

$\overline{1.00000 E-03}$

(in)

Slit or

Orifice

Depth

(in)

C

C

C

C

c

C Pressure

c Differential

c (psi)

$\overline{1.00000 E+00}$

$\overline{1.09000 \mathrm{E}-01}$

Absolute

Surface

Roughness

(in)

0.00006 tube

Contraction

Coefficient

0.0018 steet

0.61 and

1.00 and

0.0102 iron

1.00

and

Velocity

Coefficient

0.98 for sharp edge orifice

0.98 for rounded orifice

c

$\overline{1.25000 E+02}$

$\overline{1.80000 \mathrm{E}-03}$

$\longdiv { 1 . 0 0 0 0 0 \mathrm { E } + 0 0 }$

0.82 for square edge orifice

$8.20000 \mathrm{E}-01$ 


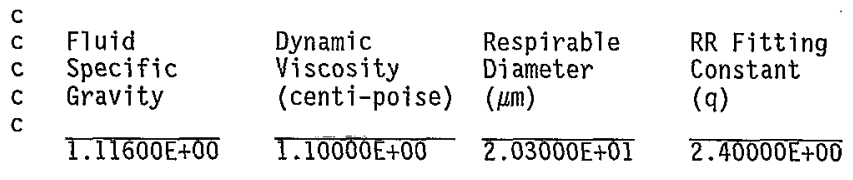

MESSAGES:

Slit Mode 1

Code search for optimal equivalent diameter.

Friction factor based on Taminar flow.

\section{OUTPUT:}

Liquid Velocity $=$ Reynolds Number $=$

Sauter Mean Diameter $=$

$8.54 \mathrm{E}+01 \mathrm{ft} / \mathrm{s}$

2. $43 \mathrm{E}+03$ Critical Flow

Optimum Sijt Width $=1.81 E-03$ in

Respirable Fraction $=4.12 \mathrm{E}-01$

Total Leak Rate $=4.82 \mathrm{E}-01 \mathrm{gpm}$

Respirable Leak Rate $=1.98 \mathrm{E}-01 \mathrm{gpm}$

$4.60 E-05 \mathrm{~m}$

$3.04 \mathrm{E}-05 \mathrm{~m} 3 / \mathrm{s}$

$1.25 \mathrm{E}-05 \mathrm{~m} 3 / \mathrm{s}$

$3.40 \mathrm{E}+01 \mathrm{~g} / \mathrm{s}$

$1.40 \mathrm{E}+01 \mathrm{~g} / \mathrm{s}$ 
SPRAY Version 3.0

May 3, 1994

Spray Leak Code

Produced by Radiological \& Toxicological Anatysis

Westinghouse Hanford Company

Run Date $=08 / 21 / 96 /$

Run Time $=08: 28: 44.89$

INPUT ECHO:

c unmitigated caustic spray - $15 \% \mathrm{NaOH}$

c SPRAY Version 3 Input Deck

c mode iflow iopt

c

21 T

c MODEL OPTIONS:

$c$ mode $=1$ then orifice $]$ eak with friction assumed

c 2 then slit leak with friction assumed

c iflow= 0 Reynold's number determines friction relation (i.e. laminar or turb.

c $\quad=1$ friction based on laminar relation

$=2$ friction based on turbulent relation

c iopt $=\mathrm{T}$ then optimal diameter search performed

$c \quad=F$ then no optimal search

$C$

PARAMETER INPUT:

C

c Initial Slit

c Width or

c Orifice Dia.

c (in)

c

c

$\overline{1.00000 E-03}$

S1it

Length

S7it or

(in)

Orifice

Depth

(in)

$\overline{1.00000 \mathrm{E}+00}$

$\overline{1.09000 E-01}$

Absolute

Surface

Roughness

(in)

Pressure

0.00006 tube

Contraction

Coefficient Coefficient

Velocity

Differential

0.0018 stee1

0.0102 iron

0.61

and

1.00 and

0.98 for sharp edge orifice

(psi)

1.00

and

0.98 for rounded orifice

0.82 for square edge orifice

$\longdiv { 1 . 2 5 0 0 0 \mathrm { E } + 0 2 }$

$1.80000 \mathrm{E}-03$

$\overline{1.00000 E+00}$

$8.20000 E-01$ 


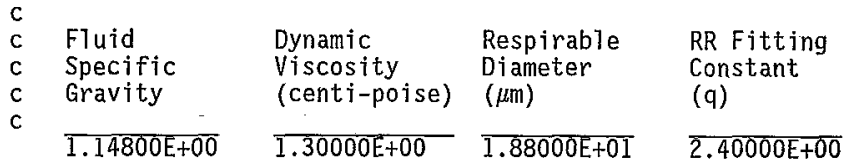

MESSAGES :

Slit Model

Code search for optimal equivalent diameter.

Friction factor based on Taminar flow.

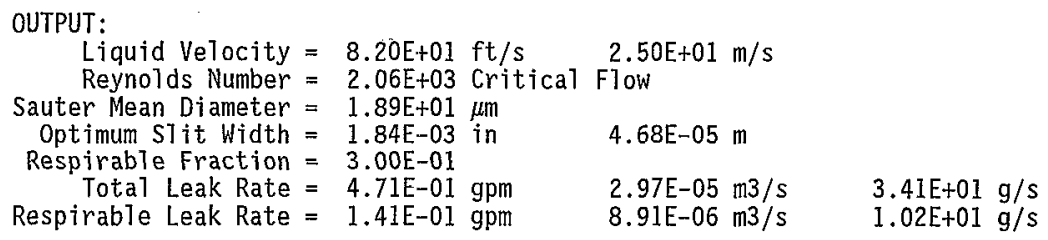


SPRAY Version 3.0

May 3, 1994

Spray Leak Code

Produced by Radiological \& Toxicological Analysis

Westinghouse Hanford Company

Run Date $=08 / 21 / 96 /$

Run Time $=08: 36: 42.36$

INPUT ECHO:

c unmitigated caustic spray - $20 \% \mathrm{NaOH}$

c SPRAY Version 3 Input Deck

c mode jflow jopt

$\begin{array}{llll}2 & 1 & \mathrm{~T}\end{array}$

c

c MODEL OPTIONS:

$c$ mode $=1$ then orifice leak with friction assumed

c. 2 then slit leak with friction assumed

c iflow= 0 Reynold's number determines friction relation (i.e. Taminar or turb.

$\mathrm{c} \quad=1$ friction based on 1 aminar re]ation

c $\quad=2$ friction based on turbulent relation

c iopt $=T$ then optimal diameter search performed

$c=F$ then no optimal search

C

C PARAMETER INPUT:

$\mathrm{C}$

c Initial Slit

c Width or

c Orifice Dia.

c (in)

C

$\overline{5.00000 E-03} \overline{1.00000 E+00} \overline{1.09000 E-01}$

C

c

C

c

c

c

Pressure
Differential

STit

Length

STit or

Orifice

(in)

Depth

(in)

c (psi)

Absolute

Surface

Roughness

(in)

Contraction

Coefficient

Velocity

0.00006 tube

0.61 and

Coefficient

0.0018 steel

1.00

and

0.98 for sharp edge orifice

0.0102 iron

1.00

and

0.98 for rounded orifice

$\overline{1.25000 \mathrm{E}+02}$

$1.80000 \mathrm{E}-03$

$\overline{1.00000 E+00}$

0.82 for square edge orifice

8.20000E-01 
C

C Fluid

Dynamic

Respirable

Specific

Viscosity

Diameter

c Gravity

(centi-poise)

( $\mu \mathrm{m})$

RR Fitting

C

$\longdiv { 1 . 2 0 2 0 0 E + 0 0 }$

$\overline{1.90000 E+00} \overline{1.71000 E+0 I}$

(q)

$\overline{2.40000 \mathrm{E}+00}$

MESSAGES:

ST jt Model

Code search for optimal equivalent diameter.

Friction factor based on Taminar flow.
OUTPUT :
Liquid Velocity $=7.83 \mathrm{E}+01 \mathrm{ft} / \mathrm{s}$
Reynolds Number $=1.61 \mathrm{E}+03$ Laminar Flow
Sauter Mean Diameter $=2.48 \mathrm{E}+01 \mu \mathrm{m}$
Optimum S7it Width $=2.10 \mathrm{E}-03$ in
Respirable Fraction $=1.38 \mathrm{E}-01$
Total Leak Rate $=5.14 \mathrm{E}-01 \mathrm{gpm}$
Respirable Leak Rate $=7.07 \mathrm{E}-02 \mathrm{gpm}$
$2.39 \mathrm{E}+01 \mathrm{~m} / \mathrm{s}$
5. 34E-05 m
$3.24 \mathrm{E}-05 \mathrm{~m} 3 / \mathrm{s}$
$4.46 \mathrm{E}-06 \mathrm{~m} 3 / \mathrm{s}$
$3.90 \mathrm{E}+01 \mathrm{~g} / \mathrm{s}$
$5.36 \mathrm{E}+00 \mathrm{~g} / \mathrm{s}$ 
SPRAY Version 3.0

May 3,1994

Spray Leak Code

Produced by Radiological \& Toxicological Analysis

Westinghouse Hanford Company

Run Date $=08 / 21 / 96 /$

Run Time $=08: 39: 43.06$

INPUT ECHO:

c unmitigated caustic spray - $30 \% \mathrm{NaOH}$

c SPRAY Version 3 Input Deck

c mode iflow iopt

$200 \quad T$

c

c MODEL OPTIONS:

$c$ mode $=1$ then orifice leak with friction assumed

c 2 then slit leak with friction assumed

c iflow 0 Reynold's number determines friction relation (i.e. laminar or turb.

c $=1$ friction based on laminar relation

$c=2$ friction based on turbulent relation

$c$ iopt $=\mathrm{T}$ then optimal diameter search performed

$c=F$ then no optimal search

$C$

c PARAMETER INPUT:

c

c Intial slit

c Width or

c Orifice Dia.

c (in)

c

$5.00000 E-03$

Siit

Length

(in)

\section{$\overline{1.00000 E+00}$}

Absolute

Surface

Roughness

Pressure

Differential

(psi)

$\longdiv { 1 . 2 5 0 0 0 \mathrm { E } + 0 2 }$

$$
\text { (in) }
$$

0.00006 tube

0.0018 steel

0.0102 iron

$1.80000 \mathrm{E}-03$
STit or

Orifice

Depth

(in)

$\overline{1.09000 E-01}$

Contraction

Coefficient

0.61 and

1.00 and

1.00 and

$\overline{1.00000 E+00}$

Velocity

Coefficient

0.98 for sharp edge orifice

0.98 for rounded orifjce

0.82 for square edge orifice

\section{$8.20000 E-01$}




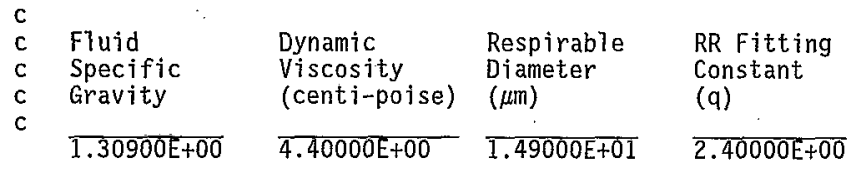

MESSAGES:

Sl it Model

Code search for optimal equivalent diameter.

OUTPUT:

Liquid Velocity $=7.40 E+01 \mathrm{ft} / \mathrm{s} \quad 2.26 E+01 \mathrm{~m} / \mathrm{s}$

Reynotds Number $=1.04 \mathrm{E}+03$ Laminar Flow

Sauter Mean Diameter $=4.77 \mathrm{E}+01 \mu \mathrm{m}$

Optimum STit Width $=3.06 \mathrm{E}-03$ in

Respirable Fraction $=2.19 \mathrm{E}-02$

Total Leak Rate $=7.06 \mathrm{E}-01 \mathrm{gpm}$

Respirable Leak Rate $=1.54 \mathrm{E}-02 \mathrm{gpm}$

$7.77 \mathrm{E}-05 \mathrm{~m}$

$4.45 \mathrm{E}-05 \mathrm{~m} 3 / \mathrm{s}$

$5.83 \mathrm{E}+01 \mathrm{~g} / \mathrm{s}$

$9.74 \mathrm{E}-07 \mathrm{~m} 3 / \mathrm{s} \quad 1.28 \mathrm{E}+00 \mathrm{~g} / \mathrm{s}$ 
SPRAY Version 3.0

May 3, 1994

Spray Leak Code

Produced by Radiological \& Toxicological Analysis

Westinghouse Hanford Company

Run Date $=08 / 21 / 96 /$

Run Time $=13: 50: 03.03$

INPUT ECHO:

c unmitigated caustic spray - $40 \% \mathrm{NaOH}$

c SPRAY Version 3 Input Deck

c mode iflow iopt

$200 \quad T$

C

c MODEL OPTIONS:

$c$ mode $=1$ then orifice leak with friction assumed

c 2 then slit leak with friction assumed

c iflow= 0 Reynold's number determines friction relation (i.e. laminar or turb.

c $=1$ friction based on laminar relation

$c \quad=2$ friction based on turbulent relation

c iopt $=T$ then optimal diameter search performed

$c=F$ then no optimal search

c

C PARAMETER INPUT:

C

c Initial slit

c Width or sTit

c Orifice Dia.

c (in)

c

5.00000E-03

Length

STit or

(in)

Orifice

Depth

(in)

C

C

c

c

c

c

\section{Differential}

Pressure

\section{$1.00000 E+00$}

\section{$\overline{1.09000 E-01}$}

Absolute

Surface

(psi)

Roughness

(in)

0.00006 tube 0.61 and

Contraction

Coefficient

Velocity

Coefficient

0.98 for sharp edge orifice

0.98 for rounded orifice

0.0102 iron 1.00 and

0.82 for square edge orifice

C

$\overline{1.25000 \mathrm{E}+02}$

$\overline{1.80000 \mathrm{E}-03}$

$\overline{1.00000 E+00}$

$8.20000 E-01$ 


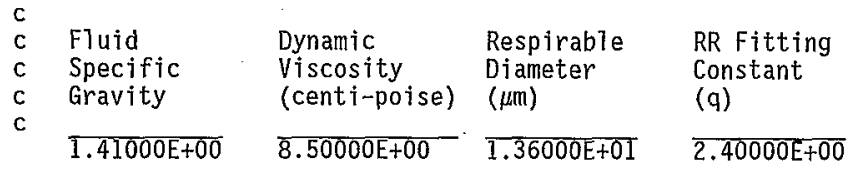

MESSAGES:

S1 it Mode1

Code search for optimal equivalent diameter.

OUTPUT:

Liquid Velocity $=7.09 \mathrm{E}+01 \mathrm{ft} / \mathrm{s}$

Reynolds Number $=7.48 \mathrm{E}+02$ Laminar Flow

Sauter Mean Diameter $=8.02 \mathrm{E}+01 \mu \mathrm{m}$

Optimum S1 it Width $=4.13 \mathrm{E}-03$ in

Respirable Fraction $=5.10 \mathrm{E}-03$

Total Leak Rate $=9.12 \mathrm{E}-01 \mathrm{gpm}$

Respirabie Leak Rate $=-4.65 \mathrm{E}-03 \mathrm{gpm}$

$1.05 \mathrm{E}-04 \mathrm{~m}$

$5.75 \mathrm{E}-05 \mathrm{~m} 3 / \mathrm{s}$

$2.93 \mathrm{E}-07 \mathrm{~m} 3 / \mathrm{s}$

8.11E+01 g/s

$4.14 \mathrm{E}-01 \mathrm{~g} / \mathrm{s}$ 
SPRAY Version 3.0

May 3, 1994

Spray Leak Code

Produced by Radiological \& Toxicological Analysis Westinghouse Hanford Company

Run Date $=08 / 21 / 96 /$

Run Time $=13: 52: 17.92$

INPUT ECHO:

c unmitigated caustic spray - $50 \% \mathrm{NaOH}$

c SPRAY Version 3 Input Deck

c mode iflow iopt

$\mathrm{C}$

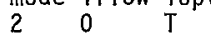

c MODEL OPTIONS:

c mode $=1$ then orifice leak with friction assumed

c 2 then slit leak with friction assumed

$c$ jflow= 0 Reynold's number determines friction relation (i.e. laminar or turb.

c $=1$ friction based on laminar relation

$c=2$ friction based on turbulent relation

$c$ iopt $=T$ then optimat diameter search performed

$c=F$ then no optimal search

c

C PARAMETER INPUT:

$C$

c InitiaT Slit

c Width or

c Orifice Dia.

c (in)

c.

c

$\overline{5.00000 E-03} \quad \overline{1.00000 E+00} \quad \overline{1.09000 E-01}$

Slit Orifice

Length Depth

(in) (in)

c

c

c

c

C

c Differential

C (psi)

c

$\overline{1.25000 E+02}$

Absolute

Surface

Roughness

(in)

Contraction

Coefficient

Velocity

0.00006 tube 0.61 and

Coefficient

0.0018 stee 1.00 and

0.98 for sharp edge orifice

0.0102 iron 1.00 and

0.98 for rounded orifice

0.82 for square edge orifice

$\overline{1.80000 E-03} \quad \overline{1.00000 E+00}$

$8.20000 \mathrm{E}-01$ 


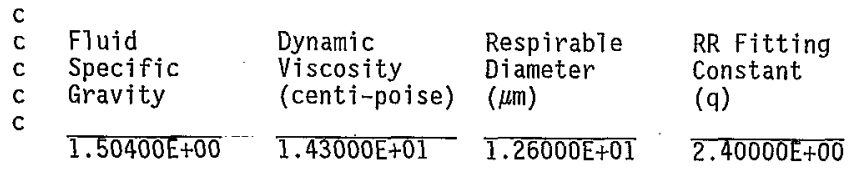

MESSAGES:

ST it Model

Code search for optimal equivalent diameter.

OUTPUT:

Liquid Velocity $=$ Reynolds Number =

Sauter Mean Diameter $=$

Optimum Slit Width $=5.30 \mathrm{E}-03 \mathrm{in}$

Respirable Fraction $=1.55 \mathrm{E}-03$

Tota1 Leak Rate $=1.14 \mathrm{E}+00 \mathrm{gpm}$

Respirable Leak Rate $=1.77 \mathrm{E}-03 \mathrm{gpm}$
$1.22 \mathrm{E}+02 \mu \mathrm{m}$

$6.88 \mathrm{E}+01 \mathrm{ft} / \mathrm{s}$

$5.91 \mathrm{E}+02$ Laminar Flow

$2.10 \mathrm{E}+01 \mathrm{~m} / \mathrm{s}$

I. $35 \mathrm{E}-04 \mathrm{~m}$

$7.18 \mathrm{E}-05 \mathrm{~m} 3 / \mathrm{s}$

$1.11 \mathrm{E}-07 \mathrm{~m} 3 / \mathrm{s}$
$1.08 \mathrm{E}+02 \mathrm{~g} / \mathrm{s}$

1. $68 \mathrm{E}-01 \mathrm{~g} / \mathrm{s}$ 


\section{CHECKLIST FOR PEER REVIEW}

\section{Document Reviewed: CONSEQUENCE ANALYSIS OF A NaOH SOLUTION SPRAY RELEASE} DURING ADDITION TO WASTE TANK, D.A. Himes, $10 / 3 / 96$

Scope of Review: entire document

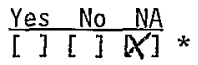

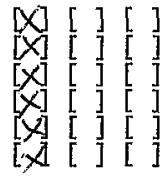

$[X][$ [ ]

[X] [ ] [ ]

LC] [ ] [ ]

$[x]\left[\begin{array}{lll}1 & {[}\end{array}\right]$

Previous reviews complete and cover analysis, up to scope of this review, with no gaps.

Problem completely defined.

Accident scenarios developed in a clear and logical manner.

Necessary assumptions explicitly stated and supported.

Computer codes and data files documented.

Data used in calculations explicitly stated in document.

Data checked for consistency with original source information as applicable.

Mathematical derivations checked including dimensional consistency of results.

Models appropriate and used within range of validity or use outside range of established validity justified.

Hand calculations checked for errors. Spreadsheet results should be treated exactly the same as hand calculations.

Software input correct and consistent with document reviewed.

Software output consistent with input and with results reported in

[X] [ ] [W] BEst Locument reviewed. appropriate and referenced. Limits/criteria/guidelines checked against references.

$[x]\left[\begin{array}{lll}] & {[} & ] \\ {[} & ] & {[}\end{array}\right]$

Safety margins consistent with good engineering practices.

Conclusions consistent with analytical results and applicable Timits.

[D] [ ] [ ] Results and conclusions address all points required in the problem statement.

[ ] [ ] [X]

[ ] [X] * Review ca]culations, comments, and/or notes are attached.

[X] [ ] [ ] Document approved.

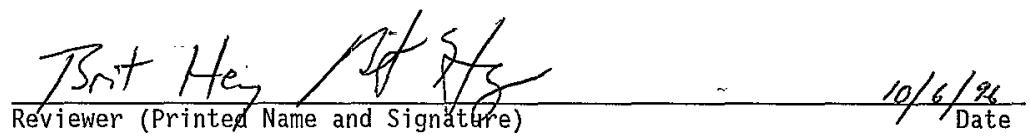

* Any calculations, comments, or notes generated as part of this review should be signed, dated and attached to this checki ist. Such material should be labeled and recorded in such a manner as to be intelligible to a technically qualjified third party. 


\section{HEDOP REVIEW CHECKLIST \\ for}

, Radiological and Nonradiological Release Calculations

Document reviewed (include title or description of calculation, document number, author, and date, as applicable):

\section{CONSEQUENCE ANALYSIS OF A NaOH SOLUTION SPRAY RELEASE DURING ADDITION}

TO WASTE TANK, D.A. Himes, 10/3/96

Submitted by: D.A. Himes

Date Submitted:

Scope of Review: entire document

YES NO* N/A

[X] [ ] [ ] 1. A detailed technical review and approval of the environmental transport and dose calculation portion of the analysis has been performed and documented.

L1 [ ] [ ] 2. Detai]ed technical review(s) and approva](s) of scenario and

[ ] [ ] [4] 3. HEDOP-approved code(s) were used.

[य] [] [] 4. Receptor locations were selected according to HEDOP recommendations.

[4] [ ] [ ] 5. A]1 app1icable environmenta] pathways and code options were

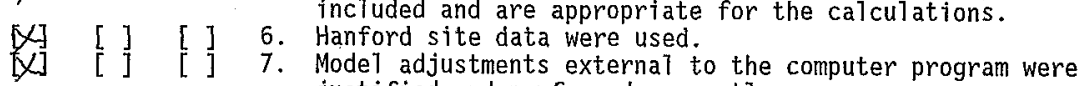
justified and performed correctiy.

[ ] [ ] [ 4 8. The analysis is consistent with HEOOP recommendations.

[ $]$ [x] 9. Supporting notes, calculations, comments, comment resoTutions, or other information is attached. (Use the "Page 1 of $X$ " page numbering format and sign and date each added page.)

[4 [ ] 10. Approval is granted on behalf of the Hanford Environmental Dose Overview Panel.

* ATl "NO" responses must be explained and use of nonstandard methods justified.

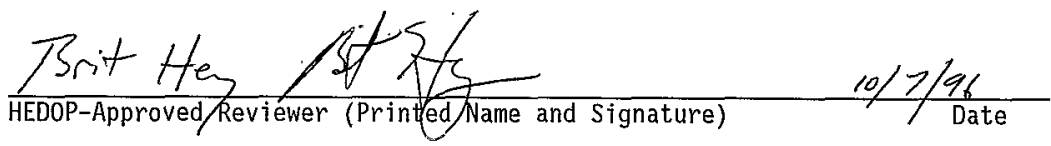

COMMENTS (add additional signed and dated pages if necessary): 


\section{DISTRIBUTION SHEET}

\begin{tabular}{|c|c|c|c|c|c|}
\hline \multirow{2}{*}{$\begin{array}{l}\text { To } \\
\text { Consequence Analysis } 8 M 400\end{array}$} & \multirow{2}{*}{\multicolumn{3}{|c|}{$\begin{array}{l}\text { From } \\
\text { Consequence Analysis } 8 M 400\end{array}$}} & \multicolumn{2}{|l|}{ Page 1 of 1} \\
\hline & & & & \multicolumn{2}{|c|}{ Date $10 / 7 / 96$} \\
\hline \multirow{2}{*}{\multicolumn{4}{|c|}{$\begin{array}{l}\text { Project Title/Work Order } \\
\text { Consequence Analysis of a } \mathrm{NaOH} \text { Solution Spray Release During } \\
\text { Addition to Waste Tank }\end{array}$}} & \multirow{2}{*}{\multicolumn{2}{|c|}{$\begin{array}{ll}\text { EDT No. } & \text { N/A } \\
\text { ECN No. } & 609892\end{array}$}} \\
\hline & & & & & \\
\hline Name & MSIN & $\begin{array}{l}\text { Text } \\
\text { With All } \\
\text { Attach. }\end{array}$ & - Text Only & $\begin{array}{l}\text { Attach./ } \\
\text { Appendix } \\
\text { Only }\end{array}$ & $\begin{array}{l}\text { EDT/ECN } \\
\text { Only }\end{array}$ \\
\hline $\begin{array}{l}\text { C. Carro } \\
\text { G.W. Ryan } \\
\text { B.E. Hey } \\
\text { D.A. Himes (2) } \\
\text { Central Files (originaT }+1 \text { ) } \\
\text { Docket Files (2) } \\
\text { TWRS S\&LFiles }(2)\end{array}$ & $\begin{array}{l}\text { A2-34 } \\
\text { A3-37 } \\
\text { A3-34 } \\
\text { A3-34 } \\
\text { A3-88 } \\
\text { B1-17 } \\
\text { A2-26 }\end{array}$ & $\begin{array}{l}X \\
X \\
X \\
X \\
X \\
X \\
X\end{array}$ & & & \\
\hline
\end{tabular}

